\title{
IMPACT OF AGRICULTURAL SECTOR INVESTMENTS ON INCOME DISTRIBUTION AND POVERTY IN CENTRAL SULAWESI, INDONESIA
}

\author{
Rustam Abd. Rauf ${ }^{(1)}$, Arief Daryanto ${ }^{2)}$, D.S. Priyarsono ${ }^{3)}$ \\ ${ }^{1)}$ Agribusiness Department, Tadulako University, Palu- Indonesia, e-mail : rustam@untad.ac.i d \\ 2),3) Department of Resources and Environmental Economics, Bogor Agriculture University, Bogor-Indonesia,
}

\begin{abstract}
Central Sulawesi is a province in Indonesia with abundant natural resources particularly in agricultural sector. This condition suggests that the agricultural sector plays a very significant role in Central Sulawesi economy. One of the causal factors leading to the disparity of income distribution and poverty is investment allocation with its inconsistency occurs in sectoral development planningThe Gini Ratio of Central Sulawesi Province was 0.4844 in 2008 reflecting moderate level of income disparity for the income distribution among household groups. Simulation of increasing investment on agricultural and other sectors for $10 \%$ can generally decrease poverty at all groups of households both in rural and urban area. Simulation 2 (investment in plantation subsector) led to highest poverty decline as comparison to other simulation.
\end{abstract}

Keywords: Income distribution, Investment, Poverty, and SAM model.

\section{INTRODUCTION}

Agricultural sector plays a very significant role in national economy. Priyarsonoet.al. (2008) stated that many countries achieved their take-off phase toward sustainable economy driven by industry and service sectors which are preceded by the advance in agricultural sector. The yearly report of World Bank (2000) stated that the growth of PDB on the basis of agricultural sector is four times more effective in decreasing poverty than other sectors. This is associated with the ability of the agricultural sector in absorbing and creating employment (pro-employment). Moreover, the agricultural sector has greater multiplier effect regarding to forward and backward linkages, particularly its processing industry and service, than other sectors (Daryanto, 2009).

Central Sulawesi is a province in Indonesia with abundant natural resources particularly in agricultural sector as indicated by this sector contribution to the province's PDRB is IDR 11.897 billion in 2008 with its PDRB distribution of $42.26 \%$ (BPS Sulawesi Tengah, 2009). Labors working at the agricultural sector were 721,877 people $63.8 \%$ of Central Sulawesi population of $1,131,706$ people. This condition suggests that the agricultural sector plays a very significant role in Central Sulawesi economy. It is in contrast with the people welfare in which 213,062 of 572,614 existing house holds in the region fall into poor and very poor category and ironically most of them live in rural areas which are the basis of the agricultural sector (Bappeda Sulawesi Tengah, 2009).

One of the causal factors leading to the disparity of income distribution and poverty is investment allocation with which inconsistency occurs in sectoral development planning. The allocation of 
investment both by local government and private tend to be bias to industry sector as indicated by the last five year investment on the agricultural sector which range only from $3-6 \%$, while it is an important factor in determining the success of region development as it drives the growth of economy sector.Daryanto (2009) stated that economic growth with little support from investment is low quality growth due to its reliance to external growth i.e. price of several export commodities. In Keynes macro economy theory, increasing investment will not only improve aggregate demand but also aggregate supply through its effect on production capacity. These two roles lead the investment to have great multiplier effect in the Central Sulawesi Province economy. Besides the model of HarroldDomar explained that in a long term, investment will raise supply through capital stock increasing which in turn improving people ability to produce outputs or production activities.

\section{RESEARCH METHODS}

Research Objects. The research was conducted in Central Sulawesi Province of Indonesia due to its abundant agricultural sector resources.

Types and Data Sources. The type of data used to build system model of economicsocial equilibrium in Central Sulawesi was depicted in input - output table of 2005, sectoral aggregation, suseda 2005, susenas Indonesia 2005, agriculture statistic, special survey of household saving dan investment 2008, people welfare indicator 2008, local government budget, regional capital investment, domestic product regional bruto, Production and Trade of Agricultural Sector, other data, balancing SAM 2008.

Frame Construction of Social Accounting Matrix (SAM) of Central Sulawesi . The Social Accounting Matrix (SAM) is a system of national/regional/sub-regional accounts represented in a matrix format (Pasquale L.S. and Cataldo F., 2015).
Starting from a base year SAM from a national/regional accounting data base, we develop a methodology (Scandizzo, 1992; Scandizzo, Ferrarese, and Vezzani, 2010; Margarita et.al. 2015) to estimate a SAM on the basis of aricher information database constituted by a combination of time series of national accounts and household surveys. Basic data used in the SAM model of Central Sulawesi was the input-output (IO) Table of 2005.As in the IO model, the aggregation of information plays an important role within the SAM framework (Maria Llop and Antonio M., 2014; Alvaro G. and Cristian M., 2013). Considering that the analyzed production sector was focused on agricultural sector whilst this sector was in the input-output Table of 2005 consisted of $50 \times 50$ sectors then it was aggregated into 22 sectors, and the sectors of agriculture was aggregated into 5 subsectors of agriculture.

\section{Analysis Methods}

\section{Multiplier Analysisof Equilibrium}

The math's model of the multiplier analysis of equilibrium in this research is as follows:

$A_{i j}=T_{i j} t_{j}^{-1}$, or $T_{i j}=A_{i j} t_{j} \ldots \ldots \ldots \ldots \ldots \ldots \ldots \ldots \ldots \ldots \ldots \ldots \ldots \ldots \ldots \ldots \ldots \ldots \ldots \ldots . . .1(1)$

Where:

$\mathrm{A}_{\mathrm{ij}}=$ average expenditure propensity at row $\mathrm{i}$ and column $\mathrm{j}$

$\mathrm{T}_{\mathrm{ij}}=$ endogen ousequilibrium at row $\mathrm{i}$ and column j

$\mathrm{Tj} \quad=$ total column at $\mathrm{j}$

There fore, the SAM frame can be written in the form of matric as follows:



Where $\mathrm{X}$ is the column vector of Tij matric for each $\mathrm{i}=1,2,3,4$ 
(exogenousequilibrium). Because Aij is a matric with constant elements, the equation (5) can be written in the following matric:

$\left[\begin{array}{l}t_{1} \\ t_{2} \\ t_{3}\end{array}\right]=\left[\begin{array}{ccc}0 & 0 & A_{1.3} \\ A_{2.1} & A_{2.2} & 0 \\ 0 & A_{3.2} & A_{3.3}\end{array}\right]=\left[\begin{array}{l}t_{1} \\ t_{2} \\ t_{3}\end{array}\right]+\left[\begin{array}{l}X_{1} \\ X_{2} \\ X_{3}\end{array}\right] \cdots$

and

$$
t_{4}=A_{4.2} t_{2}+A_{4.3} t_{3}+X_{4}
$$

Based on the equation 4 , it can be seen that the value of $t_{4}$ can be found if $t_{2}$ and $t_{3}$ are known. The equilibrium of $t 4$ and $\mathrm{Xi}(\mathrm{i}=1,2,3,4)$ are the exogen ousequilibrium within the frame of SAM Furthermore the equation 3 can be written in matric notation as follows:

$t=A t+X$

$t-A t=X \quad(I-A) t=X$

Atau $=$ or

$t=(I-A)^{-1} X$, atau $t=M_{a} X$

Where, $M_{a}=(I-A)^{-1}$ is known as accounting multiplier equilibrium. The equation 6 explains that the endogen ousequilibrium of incomeand equilibrium production factor, institution equilibrium, and production sector equilibrium will change at a rate of $M_{a}$ due toone unit change in exogenous equilibrium. The equation 6 can be differentiated into the following general equation:

$\delta t=M_{a} \delta X$

And the following particular:

$$
\delta t_{i} / \delta X_{j}=M a_{i j}
$$

Where $\delta t_{i}$ is a change in endogenous equilibrium at $i$ (i.e. change of income in household institution), $\delta X_{j}$ is a change in exogenous equilibrium at $\mathrm{j}$ (i.e. change of government and private investment expenditure in agriculture and agricultural processing industry sectors), and $M a_{i j}$ is equilibrium multiplier at row $\mathrm{i}$ and column j.Equation 8 explains that if the expenditure of exogenous equilibrium at $\mathrm{j}$ change for one unit, then endogenous equilibrium at $i$ will change for $M a$ unit (Daryanto and Yundy, 2010; Maria Llop and Antonio M., 2014).

Poverty Analysis. The analysis of household poverty in this research used the equation of Foster - Greer - Thorbecke poverty index (Cockburn, 2001).

$\mathrm{P}_{\alpha}(\mathrm{y} ; \mathrm{z})=\frac{1}{n} \sum_{i=1}^{q}\left(\frac{z-y_{i}}{z}\right)^{\alpha}(\alpha \geq 0)$

Where:

$\mathrm{Yi}=$ the average value of expenditure per capita per individual at $i$ within household which has been ranked based on the level of expenditure

$\mathrm{n}=$ total population

$\mathrm{q}=$ number of poor population

$\mathrm{Z}=$ poverty line

Thus poverty gap ratio is $\mathrm{G}_{\mathrm{i}}=(\mathrm{z}-$ $\left.y_{i}\right) / z$, where $G_{i}=0$ at $y_{i}>z$. In this equation, the value of $\alpha=0, \mathrm{P}_{0}$ is headcount index which is the proportion of population below poverty line. The equationabove then becomes:

$\mathrm{P}_{0}(\mathrm{y} ; \mathrm{z})=\frac{1}{n} \sum_{i=1}^{q}\left(\frac{z-y_{i}}{z}\right)^{\circ}$, or $\mathrm{P}_{0}=\mathrm{q} / \mathrm{n}$

If $30 \%$ population is poor, then $\mathrm{P}_{0}=0.3$

\section{RESULTS AND DISCUSSION}

Multiplier Coefficient of Agricultural Sector for Production Sector. The multiplier coefficient of agricultural sector on the structure production sector is depicted in Table 1.

Table 1 shows that food and drink industry generally had multiplier value larger than the other sectors. The multiplier value of this sector was generated by capital equilibrium injection from agricultural sub sectors including food crop (0.0798), plantation (0.090), animal husbandry 
(0.086), forestry (0.0771), and fishery (0.101). These values mean that increasing of investment inthe agricultural sector at IDR 1 billion will be able to raise revenuein the food and drink sector in the range of IDR $0.0077-0.101$ billion. To perceive this situation deeply, there are two agricultural sub sectors that mostly affected by the increased revenue including plantation sub sector and fishery sub sector. The revenue generated in the plantation sub sector is estimatedto rise as much as IDR 0.090 billion lower than that in the fishery sub sector which is IDR 0.101 billion. High potential of fishery in Central Sulawesi is supported by its abundant resources. It spreads almostin all districts and cities of the province as it surrounded byTolo and Tomini Bays at the eastern part, and Makassar Strait and part of Sulawesi Sea at the western part. The potential of the sea riches in live lihood sources such as fish and other sea plants. This will affect the way of people life in this area particularly those who live along the coastal region.

The research done by Isrun et. al. (2009) showed that the potency of capture fisheries accessible to fishermen in Central Sulawesi is sufficiently large with production more than 200,000 $\mathrm{t}^{\text {year }}$ ${ }^{1}$ whichspreads over three utilization zones including Makassar Strait/Sulawesi Sea, Tomini Bay and Tolo Bay. Similarly, toward the end of 2007, the potency of plantation sub sector has also shown highly increasing production on priority commodities such as cacao,clove, oil palm , coconut as well as other potential commodities including coffee, cashew and vanilla.

The lowest multiplier values ranging from $0.00195-0.0029$ are found at non-oil mining and mineral sector. These values indicate that for every billion IDR increase in agricultural sector investment could increase the revenue in the range of IDR $0.00195-0.0029$ billion is generated in the non-oil mining and mineral sector. This low multiplier impact was gained by this sector due to its only existence in Palu City but not in the other eleven districts of Central Sulawesi Province.

\section{Multiplier Coefficients of Agricultural Sector for Households. Multiplier} coefficients due to injection to agricultural sector on household institution are depicted in Table 2. It shows that, any investment increase in agricultural sector generated different incomes obtained by each household category. For example, household income with multiplier values ranging from $0.5399-0.6315$ indicated that increasing investment for onebillion IDR in agricultural sector will generate income of households in the range of IDR $0.5399-0.6315$ billion. The income change expected to have the largest impact on upper class households in urban areas whilst the lowest on farm worker households at five agriculture sub sectors. Increasing investment in agricultural sector had the lowest impact on farmer worker house holds in animal husbandry sub sector with the multiplier value of 0.01416 whilst the highest on the high income group inurban areas in plantation sub sector with the multiplier value of 0.15726 . These values mean that if there is an increase in investment for onebillionIDRinagricultural sector, the income of farmerworker will rise to 0.014 billion IDR and high class house hold group in urban areas to 0.157 billion IDR. The above condition points out that the development implemented in the five agricultural sub sectorsby the government of Central Sulawesi Province in fact it could not deliver the surplus of farming system to farmer worker house hold in rural areas and it can be said that developing the five agricultural sub sectors has not yet been optimal in lessening the disparity of incomes because only the households in urban areas are benefited from it.

However, the multiplier value equilibrium above only depicts the information about income distribution according to the categorization of house holds. There fore, Giniratio is required to 
determine the extent of income disparity distribution. Sutawijaya (2004) defined criteria for determining disparity categories within community into low, moderate, and high. The criteria requirements are as follows: low if the Williamson index is $<0.35$; moderate if the index between 0.35 -0.50 ; and high if the index $>0.50$.

The calculation of Gini Ratio for Central Sulawesi was 0.4844 in 2008 suggesting that the income disparity was moderate (inequilibrium). This value means that the high income households do not invest back to production process in agricultural sector. Arsyad (1999) pointed out that the disparity in income distribution causes aggregate demand to be increasingly affected by consumption behavior of higher income households. The proportion of the higher income household expenditure is more to luxury goods than primary goods.

The results of Gini Ratio value calculation for Central Sulawesi Province is similar to that that of previous researches either in regional or national scopes. Okidama (2005) calculated Gini Ratio value for Tanjung Senang Sub District which was 0.3639 indicating that the income disparity was moderate (inequilibrium). Adnyana (2001) showed larger income disparity in Java than in outside Java i.e. the Gini Ratio values of households in Java was 0.5214 in 1995 to 0.5746 in 1999 whereas in outside Java it was 0.4762 increasing to 0.4803 . If analysis separately using Gini Ratio method and grouped into 7 house hold categories, the resultsof Gini Ratio analysis indicated that farmerworker households, low income farming, and low income non farming in rural areas tend to have even distribution, in contrast with the uneven distribution of income for higher income farm households and urban households. These results are not significantly different from that of Rauf (2001) who determined the Gini Ratio values for plantation farmers in Donggala District of Central Sulawesi Province which were in the range of $0.2-0.3$ or under low category (even), whilst the income generated outside the farming system was very unevendistribution as shown by the Gini Coefficient value ranging from 0.5 - 0.7 .

Multiplier Coefficient of Agricultural Sector for Production Factor of Added Values. The multiplier analysis of agricultural sector for value structure of production factor added values is depicted in Table 3.

Table 3 indicates that every agricultural sub sector generates income differently from each production factor. The whole sector has multiplier values ranging from $1.4871-1.5699$. This means that increasing investment in agricultural sector for one billion IDR will raise the income of production factor in the range of $1.4871-1.5699$ billionIDR. The impact of production factor of labor in agricultural and non-agricultural sectors is less than the capital of production factor.

Forestry sub sector with multiplier value of 1.0862 had larger impact on equilibrium of value added production factor than any other sub sectors. The largest impact among the production factors itself is provided by capital factor. Plantation sector shows the highest multiplier value of 0.2855 in labor production factor of agricultural sector whilst in non-labor of non-agricultural sector i.e. fishery sector has multiplier valueof 0.2083. These impact differences eventually cause disparity in increasing service return received by the production factor for each additional unit in agricultural sector.

This finding indicates that the production process occurred in Central Sulawesi was still capital intensive, therefore, service return contributed to capital production factor was more than that to agricultural labor and non-labor production factors. This elaboration means that development conducted in Central Sulawesi Province to drive the economy 
sectors for enhancing economy growth and community welfare had not been involved the community yet or was more likely capital intensive. Suratman (2004) showed similar results in West Kalimantan, more contribution is generated by capital factor than labor factor suggesting that its production process is capitally intensive. Previous research in Riau Province also found factorial income distribution was capital intensive. This is in contrast with that in North Sumatera and Southeast Nusa where the production process was force labor intensive (Ginting, 2006; Sutomo, 1995).

Impact of Agricultural Sector Investment on Poverty. Calculation of poverty indices in each household in Central Sulawesi Province used data of household expenditure average below poverty line. The poverty line defined by Central Sulawesi BPS of 2005 which was IDR 217,529 for urban areas and IDR 182,241 for rural areas. This data then were used as basic data for calculating poverty indices. Changes of household income resulting from policy simulation were assumed as after simulationdata. The tool analysis for calculating poverty indices used DAD 4.3 (Distributive analysis) Program. The results of poverty analyses according to the household categorization in Central Sulawesi Province are depicted in Table 4.

The results of head-count index values in Table 4 range from 0.961 16.197. These values indicate that the level of household poverty was vary between 0.961 - 16.197 percent. Group with the highest poverty level was the farmworker households while that with lowest one was the upper class of cities. Separating between rural households and urban households, the poor households in rural and urban areas were in the range of $2.463-$ 16.197 percent and $0.961-4.366$ percent, respectively. The number of poor households in the rural areas is much higher than in the urban areas. The source of poverty is mostly prevailed in rural areas
(Thorbecke and Pluijm, 1993). This result is strengthened by Yusdjaet. al. (2003) pointing out that more than 62 percent of poor household force labor worked in the agricultural sector living in the rural areas followed by those who worked in trade sector i.e. small traders $(10 \%)$, household industry (7\%) and services (6\%). Sources of poverty in rural areas were identifiable as (1) farmers with land less than 0.25 ha, (2) farm worker with income less or only sufficient for one day consumption, (3) fishermen who has no access to government's soft credits, and (4) forest encroachers and unemployment whereas that in urban areas were (1) factory labors, (2) lower-class government officer or private workers, (3) casual employees, (4) household maids, (5) street vendors, (6) scavengers, and (7) unemployment.

Table 4 shows that the simulation of increasing investment in the agriculture, agro-processing industry, and other sectors generally were capable to decrease the level of poverty at all household groups in both rural and urban areas. However, the highest decline in the number of poor households was generated by plantation sub sector (SIM 2) which was $-0.077 \%$ in the urban areas and $-0.065 \%$ in rural areas. The poor households groups, thenumber of lower income farm households is the most reduced in the rural areas while in the urban areas the upper income households. The highly significant effect of the plantation sub sector in decreasing the poor due to it great economic value created from wide open market share both domestically and internationally. In Central Sulawesi Province, the total income of a farm household who grown coconut-clove-cacao was IDR 3.248,60 million per month in average (Rauf, 2001). Agricultural development and rural areas are significantly important for reducing poverty in Indonesia (Booth, 2000). Similarly, O'Ryan and Sebastian (2003); Simatupang dan Darmarejo (2003) stated that PDB generated from agricultural sector has greater impact on poverty incidences in 
rural areas than any other sector. The research results of Bautista (2000) also showed that by means of AgriculturalBased Development (ABD) strategy, economic growth can be improved while decreasing the disparity of income between households.

\section{CONCLUSIONS AND RECOMMENDATIONS}

Based on the research results, it can be concluded as follows:

1. Plantation and fishery sub sectors have greater influence on production sector than the other three sectors (i.e. food crop, animal husbandry, and forestry sub sectors). Non-oil mining and mineral sector has the lowest production multiplier coefficient.

2. The Gini Ratio of Central Sulawesi Province was 0.4844 in 2008 reflecting moderate level of income disparity for the income distribution among household groups.

3. Capital production factor is still greater than any other production factor in Central Sulawesi Province indicating capital intensive driven production process in which service return given to the capital production factor is thus more than that to the labor production factor.

4. Simulationof investmentincreasing on agricultural and other sectors for $10 \%$ can generally decrease poverty at all groups of households both in rural and urban areas. Simulation 2 (investment in plantation subsector) lead to highest poverty decline as comparison to other simulation.
Some efforts to raise the performance of Central Sulawesi Economy with reference to this researchlead to the following policies considered important to the regional government are :

1. Increasing investment policy at all agricultural subsectors particularly plantation which can give positive influence on output, equal income distribution and poor household reduction.

2. Implementing technology policy at farmworker and lower income households by means of human resources development which enable them to adapt and apply technology in order to increase income leading to lessen the income disparity and poverty.

Based on the research results, conclusions and policy implementation, it is recommendedthat:

1. The research should be continued using SAM model by disaggregating each government expenditure on agricultural sector thus the role of each expenditure can be identified.

2. Further research to compare between agricultural sector and non-agricultural sector at every districts within Central Sulawesi Province or to compare them based on regional typology (coastal and mountainous region) which have strong economic link using several econometric models, thus it can enrich regional economy research and give recommendations to regional and central government for optimizing regional economy potency either in the level of province, districts or cities.

\section{REFERENCES}

Adnyana, M.O. (2001). Struktur Pendapatan dan Pengeluaran Rumah Tanggapan dan berbagai Agroekosistem di Wilayah Sumatera, Jawa-Bali dan Kalimantan. Makalah disampaikan pada Seminar Rutin PSE November 2001.

Alvaro Gallardo and Cristian Mardones. (2013). Environmentally extended social accounting matrix for Chile. Journal Environ Dev Sustain (2013) 15:1099-1127.

Arsyad, L. (1999). Ekonomi Pembangunan.Edisike`Empat. BPFE, Yogyakarta. 
Badan Pusat Statistik. (2009). Sulawesi Tengah dalam Angka. Badan Pusat Statistik Provinsi Sulawesi Tengah, Palu.

Badan Perencanaan Pembangunan Daerah Provinsi Sulawesi Tengah.(2009). Profil Daerah Sulawesi Tengah.Palu, Sulawesi Tengah.

Bautista, R.M. (2000). Agriculture-Based Development: A SAM Perspective on Central Vietnam. The Developing Economics, 39 (1): 112-32.

Booth, A. (2000). Poverty and Inequality in The Soeharto Era: An Assessment. Bulletin of Indonesian Economic Studies, 36 (1): 73-104.

Cockburn, J. (2001). Trade Liberalisation and Poverty in Nepal. A Computable General Equilibrium Micro Simulation Analysis. Centre for the Study of African Economies and Nuffield College (Oxford University) and CREFA, jcoc@ecn.ulaval.ca.

Daryanto, A.(2009). Dinamika Daya Saing Industri Peternakan. IPB Press, Bogor.

Daryanto, A. and Yundy H. (2010). Analisis Input - Output dan Social Accounting Matrix untuk Pembangunan Ekonomi Daerah. IPB Press, Bogor.

Ginting, R. (2006). Dampak Pengeluaran Pemerintah terhadap Pertumbuhan dan Distribusi Pendapatan di Sumatera Utara: Pendekatan Sistem Neraca Sosial Ekonomi. Disertasi Doktor (tidak dipublikasikan). Program Pascasarjana Institut Pertanian Bogor, Bogor.

Isrun, Syamsuddin L, and Parman P. (2009).Survey dan Pemetaan Bidang Ekonomi pada Sektor Pertanian dan Perikanan di Provinsi Sulawesi Tengah. Laporan Penelitian Kerjasama Balitbangda Provinsi Sulawesi Tengah dengan UniversitasTadulako.

Margarita Barrera-Lozano, Alfredo J. Mainarand José Vallés.(2015). Disaggregation of sectors in social accounting matrices using a customized Wolsky method. Journal Applied Economics LettersVol. 22, No. 13, 1020-1024.

Maria Llop and Antonio Manresa. (2014). Comparing the aggregation bias in the inputoutput model and the social accounting matrix model. Journal Applied Economics Letters,21(11), 795-800.

Okidama, W.F. (2005).Distribusi Pendapatan: Studi Kasus Kecamatan Tanjung Senang Kota Bandar Lampung. http://epserv.fe.unila.ac.id.

O'Ryan R. and M. Sebastian. (2003).The Role of Agriculture in Poverty Alleviation, Income Distribution and Economic Development: A CGE Analysis for Chile. Agricultural and Development Economics Division (ESA). FAO of the United Nation, Rome.

Pasquale L.S. and Cataldo F. (2015) Social accounting matrix: A new estimation methodology Journal of Policy Modeling 37 (2015) 14-34. 
Priyarsono, DS, A. Daryanto, and L.S. Kalangi. (2008). Peranan Investasi di Sektor Pertanian dan Agroindustri dalam Penyerapan Tenaga Kerjadan Distribusi Pendapatan: Pendekatan Sistem Neraca Sosial Ekonomi. Jurnal SOCA. 8 (1) : 48-57.

Rauf, R.A. (2001). Studi Komparatif Usahatani Perkebunan di Kabupaten Donggala. Tesis (Tidak dipublikasikan). Program Pascasarjana Universitas Gadjah Mada, Yogyakarta.

Scandizzo, P. L. (1992). Trade liberalization and agricultural prices. Journal of Policy Modeling, 14(5), 561-582.

Scandizzo, P. L., Ferrarese, C., and Vezzani, A. (2010). La matrice di contabilitàsociale. IlRisparmio Review, 58(3), 19-62.

Simatupang, P. and S.K. Dermorejo. (2003). Produksi Domestik Bruto, Harga dan Kemiskinan: Hipotesis "Trickle Down" Dikaji Ulang. Jurnal Ekonomi dan Keuangan Indonesia, 51 (3) : 291 - 324.

Suratman, E. (2004). Analisis Dampak Kebijakan Pengembangan Kawasan Perbatasan terhadap Kinerja Perekonomian Kalimantan Barat :Suatu Studi dengan Pendekatan Sistem Neraca Sosial Ekonomi. Disertasi Doktor (tidak dipubliksikan). Program Pascasarjana Universitas Indonesia, Jakarta.

Sutawijaya A. (2004). Analisis Disparitas Pendapatan Antar daerah dan Potensi Relatif Secara Sektoral. STEI (03) : $34-51$.

Sutomo S. (1995). Kemiskinan dan Pembangunan Ekonomi Wilayah :Analisis Sistem Neraca Sosial Ekonomi. Disertasi Doktor (tidak dipublikasikan). Program Pascasarjana Institut Pertanian Bogor, Bogor.

Thorbecke E. and T.V.D Pluijm. (1993). Rural Indonesia: Socio economic Development in a Changing Environment. IFAD. New York University Press, New York.

World Bank. (2000). Empirics of the Link between Growth and Poverty. PREM Notes Economic Policy n45, Oktober 2000.

Yusdja, Y. S. Friyanto, Ilham N, Syahyuti S, Hastuti Y. S. and Noekman KM. (1999). Monitoring dan Evaluasi Bantuan Pemerintah dalam Rangka Pemberdayaan Ekonomi Rakyat. PusatPenelitianSosialEkonomiPertanian, Bogor 


\section{Appendix}

Table1. Multiplier Coefficient of Agricultural Sector for Production Sector.

\begin{tabular}{|c|c|c|c|c|c|}
\hline Sector & $\begin{array}{l}\text { Food } \\
\text { Crop }\end{array}$ & Plantation & $\begin{array}{c}\text { Animal } \\
\text { Husbandry }\end{array}$ & Forestry & Fishery \\
\hline Oil and gas mining & 0.01140 & 0.01581 & 0.01227 & 0.03232 & 0.03356 \\
\hline Non-oil mining & 0.00195 & 0.00229 & 0.00195 & 0.00204 & 0.00210 \\
\hline Food and drink industry & 0.07989 & 0.09000 & 0.08602 & 0.07716 & 0.10164 \\
\hline Leather industry & 0.02933 & 0.03291 & 0.02967 & 0.02907 & 0.03191 \\
\hline $\begin{array}{l}\text { Woodindustry and other forestry } \\
\text { products }\end{array}$ & 0.03053 & 0.03481 & 0.03113 & 0.02975 & 0.03338 \\
\hline Paper and printed industry & 0.01156 & 0.01305 & 0.01161 & 0.01192 & 0.01260 \\
\hline $\begin{array}{l}\text { Chemical fertilizer and rubber } \\
\text { goods industry }\end{array}$ & 0.03030 & 0.05283 & 0.02944 & 0.02939 & 0.03134 \\
\hline $\begin{array}{l}\text { Cement industry, non-metal mineral } \\
\text { products }\end{array}$ & 0.01763 & 0.02007 & 0.01764 & 0.01731 & 0.01893 \\
\hline Basic iron and steel industry & 0.00998 & 0.01311 & 0.00985 & 0.01379 & 0.01289 \\
\hline $\begin{array}{l}\text { Transportation means Industry and } \\
\text { others }\end{array}$ & 0.01829 & 0.02109 & 0.01899 & 0.02323 & 0.02088 \\
\hline Electricity and clean water & 0.02905 & 0.03291 & 0.02904 & 0.02800 & 0.03160 \\
\hline Building/construction & 0.03767 & 0.04568 & 0.03788 & 0.04216 & 0.04075 \\
\hline Trade & 0.04489 & 0.04981 & 0.05416 & 0.04374 & 0.07550 \\
\hline Restaurant and hotel & 0.02855 & 0.03240 & 0.02913 & 0.02962 & 0.03200 \\
\hline Transportation and communication & 0.03137 & 0.03931 & 0.03218 & 0.04540 & 0.03780 \\
\hline $\begin{array}{l}\text { Bank, rental business, and company } \\
\text { services }\end{array}$ & 0.01796 & 0.02400 & 0.01662 & 0.02664 & 0.02219 \\
\hline $\begin{array}{l}\text { Government, defense, service and } \\
\text { other activities }\end{array}$ & 0.03602 & 0.04680 & 0.03620 & 0.04293 & 0.03956 \\
\hline Total & 0.46638 & 0.56688 & 0.48379 & 0.52449 & 0.57862 \\
\hline
\end{tabular}

Table 2. Multiplier coefficients of agricultural sector for households in 2008.

\begin{tabular}{|c|c|c|c|c|c|}
\hline Sector & $\begin{array}{l}\text { Food } \\
\text { crop }\end{array}$ & Plantation & $\begin{array}{c}\text { Animal } \\
\text { husbandry }\end{array}$ & Forestry & Fishery \\
\hline Farmworkers & 0.01461 & 0.01647 & 0.01462 & 0.01416 & 0.01564 \\
\hline Low income farming in rural areas & 0.12011 & 0.13101 & 0.11956 & 0.11165 & 0.12739 \\
\hline High income farming in rural areas & 0.08389 & 0.09564 & 0.08405 & 0.08262 & 0.09004 \\
\hline Low income group in rural areas & 0.06718 & 0.07669 & 0.06719 & 0.06491 & 0.07243 \\
\hline High income group in rural areas & 0.02558 & 0.02920 & 0.02564 & 0.02536 & 0.02744 \\
\hline Low income group in urban ar & 0.11071 & 0.12529 & 0.11072 & 0.10712 & 0.11878 \\
\hline High income group in & 0.13928 & 26 & 0.1 & 408 & 0.14940 \\
\hline Total & 0.56135 & 0.63158 & 0.56101 & 0.53990 & 0.60112 \\
\hline
\end{tabular}


Table 3. Multiplier Coefficients of Agricultural Sectors for The added values of Production Factor in 2008.

\begin{tabular}{lccccc}
\hline \multicolumn{1}{c}{ Sector } & $\begin{array}{c}\text { Food } \\
\text { Crops }\end{array}$ & Plantation & $\begin{array}{c}\text { Animal } \\
\text { Husbandry }\end{array}$ & Forestry & Fisheries \\
\hline $\begin{array}{l}\text { Labors who generate } \\
\text { wages and salaries from } \\
\text { agricultural sector }\end{array}$ & 0.21947 & 0.28558 & 0.22206 & 0.22934 & 0.25039 \\
$\begin{array}{l}\text { Labors who generate } \\
\text { wages and salaries from } \\
\text { non-agricultural sector }\end{array}$ & 0.20177 & 0.20193 & 0.19885 & 0.17160 & 0.20838 \\
\begin{tabular}{l} 
Capital \\
\multicolumn{1}{c}{ Total }
\end{tabular} & $\mathbf{1 . 0 8 5 3 2}$ & $\mathbf{1 . 0 8 2 4 1}$ & $\mathbf{1 . 0 8 5 3 4}$ & $\mathbf{1 . 0 8 6 2 3}$ & $\mathbf{1 . 0 8 3 6 7}$ \\
& $\mathbf{1 . 5 0 6 5 7}$ & $\mathbf{1 . 5 6 9 9 2}$ & $\mathbf{1 . 5 0 6 2 5}$ & $\mathbf{1 . 4 8 7 1 7}$ & $\mathbf{1 . 5 4 2 4 5}$ \\
\hline
\end{tabular}

Table 4. Simulation of Investment Increasing Policy on Poverty Incidents (Head-count Index).

\begin{tabular}{|c|c|c|c|c|c|c|c|c|c|}
\hline No & $\begin{array}{l}\text { Household } \\
\text { group }\end{array}$ & 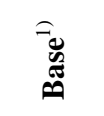 & \multicolumn{7}{|c|}{$\begin{array}{c}\text { Change }(\%)^{2)} \\
\text { Policy simulation }\end{array}$} \\
\hline \multicolumn{2}{|c|}{ Aggregate poverty } & 5.387 & SIM 1 & SIM 2 & SIM 3 & SIM4 & SIM 5 & SIM 6 & SIM 7 \\
\hline 1 & Farmerworkers & 16.197 & -0.0060 & $-0,0068$ & -0.0049 & -0.0060 & -0.0061 & -0.0061 & -0.0055 \\
\hline 2 & $\begin{array}{l}\text { Lower income } \\
\text { farming in rural } \\
\text { areas }\end{array}$ & 7.966 & $-0,0611$ & -0.0654 & -0.0508 & $-0,0545$ & -0.0535 & -0.0627 & 0.0541 \\
\hline 3 & $\begin{array}{l}\text { Upper income } \\
\text { farming in rural } \\
\text { areas }\end{array}$ & 0.00 & 0.0000 & 0.0000 & 0.0000 & 0.0000 & 0.0000 & 0.0000 & 0.0000 \\
\hline 4 & $\begin{array}{l}\text { Lower income } \\
\text { in rural areas }\end{array}$ & 2.463 & -0.0326 & -0.0371 & -0.0280 & -0.0337 & -0.0332 & -0.0328 & -0.0309 \\
\hline 5 & $\begin{array}{l}\text { Upper income } \\
\text { in rural areas }\end{array}$ & 0.00 & 0.0000 & 0.0000 & 0.0000 & 0.0000 & 0.0000 & 0.0000 & 0.0000 \\
\hline 6 & $\begin{array}{l}\text { Lower income } \\
\text { in urban areas }\end{array}$ & 4.366 & -0.0543 & -0.0611 & -0.0464 & -0.0554 & -0.0551 & -0.0547 & -0.0511 \\
\hline 7 & $\begin{array}{l}\text { Upper income } \\
\text { in urban areas }\end{array}$ & 0.961 & -0.0689 & -0.0773 & -0.0588 & -0.0694 & -0.0687 & -0.0695 & -0.0645 \\
\hline
\end{tabular}

